\title{
Impacts of Nutrition and Feeding Programs on Farmers' Management Decisions Affecting the Success of Dairy Farms with Culture Breed Cattle
}

\author{
Yavuz Topcu ${ }^{1}$, Mehmet Toparlak ${ }^{2}$, Muhlis Macit ${ }^{2}$ \\ ${ }^{l}$ Department of Agricultural Economics, College of Agriculture, Ataturk University, 25240 Erzurum, Turkey \\ ${ }^{2}$ Department of Animal Science, College of Agriculture, Ataturk University, 25240 Erzurum, Turkey.
}

\section{A R T I C L E INFO}

\section{Article history:}

Received 21 September 2015

Accepted 23 December 2015

Available online, ISSN: 2148-127X

\section{Keywords.}

Culture breeds cow

Dairy farm

Nutrition and feeding program

Principal Component Analysis

Multiple Regression Analysis

* Corresponding Author:

E-mail: yavuztopcu@atauni.edu.tr

\section{A B S T R A C T}

The aim of the study is to evaluate all the factors determining the milk production and yield decisions with regard to the nutrition and feeding programs affecting the integrated management strategies on the success of the dairy farms with culture breed cattle under the pasture-based and indoor barn-based production systems. For these aims, data obtained from the individual interviews conducted at the dairy farms with 100 culture breed cattle were used for Principal Component and Multiple Regression Analyses. The results of the study highlighted that while there were linear positive relationships among liquid assets of farms value, concentrate feed and fodder intake of dairy cattle, milk sale price, forage crop support, additional feeding and their types at pasture and milk yields per dairy cattle at the dairy farms; there were inverse relationships among hay intake of dairy cattle, lactation period, pasture planning, culture breed cattle support and those. The farmers could increase the successes of the dairy farms by increasing the technical and economic effectiveness under the integrated management pattern approaches at those with culture breed cattle.

Türk Tarım - Gıda Bilim ve Teknoloji Dergisi, 4(2): 66-72, 2016

\section{Kültür Irkına Sahip Süt Sığırcılığı İşletmelerinin Başarısını Etkileyen Çiftçilerin Yönetim Kararları Üzerinde Besin ve Besleme Programlarının Etkileri}

\section{A K A L E B İ L G İ S İ}

Geliş 21 Eylül 2015

Kabul 23 Aralık 2015

Çevrimiçi baskı, ISSN: 2148-127X

Anahtar Kelimeler:

Kültür ırkı sığır

Sütçülük işletmesi

Besin ve besleme programı

Temel Bileşenler Analizi

Çoklu Regresyon Analizi

*Sorumlu Yazar:
E-mail: yavuztopcu@ atauni.edu.tr

\section{Ö Z E T}

Çalışmanın amacı, kapalı ahır ve meraya dayalı üretim sistemleri altında kültür ırkı sığırlara sahip sütçülük işletmelerinin başarısı üzerinde bütünsel yönetim stratejilerini kapsayan besin ve besleme programları ile ilgili süt üretim ve verim kararlarını etkileyen bütün faktörleri değerlendirmektir. Bu amaçlar için kültür ırkı sığıra sahip 100 sütçülük işletmesinde bireysel görüşmelere dayalı anket çalışmasından elde edilen veriler, Temel Bileşenler ve Çoklu Regresyon Analizleri için kullanılmıştır. Çalışmanın sonuçları; sütçülük işletmelerinde süt hayvanı başına süt verimleri ile likit varlıkları, hayvanların konsantre ve kaba yem tüketimleri, süt satış fiyatı, yem bitkileri desteği, mera alanlarında ilave yemleme ve çeşitleri arasında doğrusal bir ilişkinin olduğunu gösterirken; süt sığırlarının saman tüketimi, laktasyon periyodu, mera planlaması ve kültür ırkı sığır desteklemeleri arasında ters bir ilişkinin mevcut olduğunu ortaya koymuştur. Bu yüzden çiftçiler, kültür ırkına sahip sütçülük işletmelerinde bütünsel yönetim modelleri yaklaşımı ile teknik ve ekonomik etkinliği iyileştirerek, işletmelerin başarılarını önemli ölçüde artırabilirler. 


\section{Introduction}

The nutrient ingredients of all the rations under the traditional and inadequate feeding programs implemented without considering the stages of the life, yield and reproductive activities of dairy cattle at the small-scales dairy farms have been considered to be the equal to each other. With these nutrition and feeding programs, therefore, it has been caused much lower productivity on the dairy cattle, even their losses. On the other hand, the negative habits and attitudes of the farmers running away from the technical and economic effectiveness levels at the dairy farms have also prevented the development and improvement of this activity unit with the comparative advantages in the research area.

It must be analyzed the effects on the animal yield, health and welfare resulting from the feeding, care and environment conditions, genetic characteristics of the dairy cows and farm management ability and financial power of the farmers. In order to achieve these; it is firstly provided an awareness to improve the technical knowledge level of the farmers about their ruminant anatomy and physiology, individual differences, genetic characteristics, milk yield, age and life cycles, determinative alternative diets, and then the effective care and feeding programs focused on all these should be prepared and applied correctly.

In particular, the success of the farms based on the productivity and the milk quality of the dairy cows is affected by the factors such as their environment, feeding, nutrition and care conditions, genetic and adaptation characteristics, the socioeconomic attributes, management ability, and dairy farming system of the farmers (West, 2014; Walsh et al., 2011; Cook and Nordlund, 2009; Topcu, 2008; Beever, 2006; Thatcher et al., 2006; Dillon, 2003). Dairy farmers could obtain higher productivity and total revenue from dairy farming by using dairy cow genotypes that are suitable to the production environment and appropriate husbandry practices.

The number of the dairy cows, the animal genetic and breed, and their life environment impacting on the quality and quantity of the dairy products at the livestock subsector with an important share within the agricultural production are the most important attributes affecting directly milk production value (Honorato et al., 2014; Walsh et al., 2011; Dobson et al., 2007; Pryce et al., 2004; Topcu, 2003). Selection of the breed and genetic traits, improving the dairy cow productivity under its care and feeding conditions along with the farm management have been much more noticeable attributes, however, rather than the increases in their numbers in recent years.

In particular, while the annual increase in the number of the culture breed dairy cow between 2000 and 2012 in Turkey and Erzurum were calculated as about 19 and $17 \%$; the culture-cross and domestic ones were found as about $0.5 \%$ decrease and $10 \%$ increase; 4 and $6 \%$ decreases, respectively. Whereas the milk production amounts of the culture and culture-cross breed dairy cows provided 25 and $25 \%$; and 10 and $22 \%$ increases at the same period respectively, furthermore; those of the domestic ones exposed to 1.5 and $4 \%$ decreases (Table 1 and 2). As taken into consideration the annual average milk yields per the dairy cow in 2012; they were computed as about 3.8 and 3.7, 2.5 and 2.9, 1.2 and 1.3 tons for the culture, culture-cross and domestic breeds, respectively and their overall average was also calculated as 2.8 and 2.7 tons.

On the other hand, the annual total milk production and the annual milk yields per dairy cow for the leader countries in the milk production and the world in 2012 were about 90.9 and 9.2 in USA, 54.0 and 4.5 in India, 37.8 and 30.1 in China, 32.3 and 14.2 in Brazil, 31.6 and 8.1 in Russian Federation, 24.0 and 3.6 in France, and 625.8 million tons and 2.3 tons, respectively (FAOSTAT, 2013). As compared with the leader countries; the milk yield per dairy cows in Turkey and Erzurum was a much lower than those of them, and thus the milk yield per those should be increased considerably.

In order to achieve this, it should be applied the integrated management strategies (considering farms' macro and micro environment factors along with internal factors) focused on the relationships among the milk yield and quality, the ration composition/components and quality, the production and management strategies, and the financial power of the farmers at the farms with the dairy culture cattle. With the integrated management approach, the ration components and qualities having a fundamental influence on the yield, health and welfare of the dairy cows affect considerably the quality, quantity and reliability of the milk, revenue of the farmers, and their environment conditions (West, 2014; Cook and Nordlund, 2009; Slots et al., 2009; Topcu, 2008; Cavalieri et al., 2006; Pryce et al., 2004). In order to provide balance among these attributes, therefore, their nutritional requirements under the scientific nutrition and feeding programs based on the integrated farm management strategies must be met properly.

Combined with all the factors impacting on the successes of the dairy farms with the culture breed cow under the integrated management strategies, the scientific studies have not existed in recent years. However, various researches were only reported the technical relationships between the milk yield of the dairy cows and their nutrition and feeding programs (Neveu et al., 2014; Topcu et al., 2014; West, 2014; Slots et al., 2009; Topcu, 2008; Beever, 2006; Cavalieri et al., 2006; Dillon et al., 2003); and their reproduction, insemination and fertility (Walsh et al., 2011; Dobson et al., 2007; Cavalieri et al., 2006; Thatcher et al., 2006; Wilde, 2006; Pryce et al., 2004); and animal healthy, genetics and performance (Honorato et al., 2014; Cook and Nordlund 2009; Hansson, 2007; Beever, 2006; Ingvartsen, 2006; Mulligan et al., 2006). With this study, it could also provide an important contribution to the scientific literature, therefore, and be also filled an important gap in the scientific literature.

Consequently, this study was planned to achieve all the aims mentioned above in Erzurum province, Turkey. In the scope of this planning, the aims of the study were to determine main factors with regard to the nutrition and feeding programs affecting the milk yield accepted as an impact success indicator for the dairy farms with the culture breed cow benefiting from a pasture-based production system, and then to evaluate the effects of all the factors impacting on them under the integrated management strategies by combining these factors with other factors focused on indoor barn-based the nutrition and feeding programs and the care conditions, and thus to inform the farmers to avoid incorrect and inconsistent applications. 
Table 1 The number of dairy cows milked (head), the milk amounts produced (tons) and their percent according to the cattle breeds in Turkey

\begin{tabular}{|c|c|c|c|c|c|c|}
\hline \multirow[b]{2}{*}{ Years } & \multicolumn{2}{|c|}{ Cattle: culture breed } & \multicolumn{2}{|c|}{ Cattle: cross breed } & \multicolumn{2}{|c|}{ Cattle: domestic breed } \\
\hline & $\begin{array}{c}\text { Dairy cow } \\
\text { numbers }\end{array}$ & Milk amount & $\begin{array}{c}\text { Dairy cow } \\
\text { numbers }\end{array}$ & Milk amount & $\begin{array}{c}\text { Dairy cow } \\
\text { numbers }\end{array}$ & Milk amount \\
\hline \multirow{2}{*}{2000} & 904849 & 2639113 & 2335119 & 4591861 & 2039601 & 1501067 \\
\hline & $17.2 \%$ & $30.2 \%$ & $44.2 \%$ & $52.6 \%$ & $38.6 \%$ & $17.2 \%$ \\
\hline \multirow{2}{*}{2001} & 912411 & 2660282 & 2248877 & 4410758 & 1924526 & 1418042 \\
\hline & $17.9 \%$ & $31.3 \%$ & $44.3 \%$ & $52.0 \%$ & $37.8 \%$ & $16.7 \%$ \\
\hline \multirow{2}{*}{2002} & 850725 & 2467889 & 1971740 & 3867656 & 1570103 & 1155088 \\
\hline & $19.4 \%$ & $32.9 \%$ & $44.9 \%$ & $51.6 \%$ & $35.7 \%$ & $15.5 \%$ \\
\hline \multirow{2}{*}{2003} & 1034817 & 3215859 & 2236680 & 4568252 & 1768865 & 1730027 \\
\hline & $20.5 \%$ & $33.8 \%$ & $44.4 \%$ & $48.0 \%$ & $35.1 \%$ & $18.2 \%$ \\
\hline \multirow{2}{*}{2004} & 832711 & 3231461 & 1699804 & 4608293 & 1343206 & 1769571 \\
\hline & $21.5 \%$ & $33.6 \%$ & $43.9 \%$ & $48.0 \%$ & $34.6 \%$ & $18.4 \%$ \\
\hline \multirow{2}{*}{2005} & 925618 & 3596017 & 1717309 & 4646857 & 1355170 & 1783328 \\
\hline & $23.2 \%$ & $35.9 \%$ & $43.0 \%$ & $46.3 \%$ & $33.8 \%$ & $17.8 \%$ \\
\hline \multirow{2}{*}{2006} & 1106679 & 4295367 & 1799409 & 4884590 & 1281843 & 1687345 \\
\hline & $26.4 \%$ & $39.5 \%$ & $43.0 \%$ & $44.9 \%$ & $30.6 \%$ & $15.6 \%$ \\
\hline \multirow{2}{*}{2007} & 1299750 & 5050533 & 1698801 & 4608728 & 1230889 & 1620079 \\
\hline & $30.7 \%$ & $44.8 \%$ & $40.2 \%$ & $40.9 \%$ & $29.1 \%$ & $14.3 \%$ \\
\hline \multirow{2}{*}{2008} & 1385730 & 5380715 & 1665189 & 4520465 & 1029324 & 1353996 \\
\hline & $34.0 \%$ & $47.8 \%$ & $40.8 \%$ & $40.2 \%$ & $25.2 \%$ & $12.0 \%$ \\
\hline \multirow{2}{*}{2009} & 1470886 & 5713004 & 1686064 & 4585859 & 976198 & 1284450 \\
\hline & $35.6 \%$ & $49.3 \%$ & $40.8 \%$ & $39.6 \%$ & $23.6 \%$ & $11.1 \%$ \\
\hline \multirow{2}{*}{2010} & 1626412 & 6309065 & 1787012 & 4861835 & 948417 & 1247644 \\
\hline & $37.3 \%$ & $50.8 \%$ & $41.0 \%$ & $39.2 \%$ & $21.7 \%$ & $10.0 \%$ \\
\hline \multirow{2}{*}{2011} & 1868274 & 7239644 & 1962713 & 5341224 & 930155 & 1221560 \\
\hline & $39.3 \%$ & $52.5 \%$ & $41.2 \%$ & $38.7 \%$ & $19.5 \%$ & $8.8 \%$ \\
\hline \multirow{2}{*}{2012} & 2211242 & 8554402 & 2263400 & 6166762 & 956758 & 1256673 \\
\hline & $40.7 \%$ & $53.5 \%$ & $41.7 \%$ & $38.6 \%$ & $17.6 \%$ & $7.9 \%$ \\
\hline
\end{tabular}

*Sources: (TUIK, 2013)

Table 2 The number of dairy cows milked (head), the milk amounts produced (tons) and their percent according to the cattle breeds in Erzurum

\begin{tabular}{|c|c|c|c|c|c|c|}
\hline \multirow{2}{*}{$\begin{array}{l}\text { Year } \\
\mathrm{s}\end{array}$} & \multicolumn{2}{|c|}{ Cattle: culture breed } & \multicolumn{2}{|c|}{ Cattle: cross breed } & \multicolumn{2}{|c|}{ Cattle: domestic breed } \\
\hline & $\begin{array}{c}\text { Dairy cow } \\
\text { numbers }\end{array}$ & Milk amount & $\begin{array}{l}\text { Dairy cow } \\
\text { numbers }\end{array}$ & Milk amount & $\begin{array}{c}\text { Dairy cow } \\
\text { numbers }\end{array}$ & Milk amount \\
\hline \multirow{2}{*}{2000} & 8343 & 23186 & 73108 & 130571 & 170328 & 125702 \\
\hline & $3.4 \%$ & $8.3 \%$ & $29.0 \%$ & $46.7 \%$ & $67.6 \%$ & $45.0 \%$ \\
\hline \multirow{2}{*}{2001} & 8863 & 24631 & 79399 & 141806 & 145032 & 107034 \\
\hline & $3.8 \%$ & $9.0 \%$ & $34.0 \%$ & $51.9 \%$ & $62.2 \%$ & $39.1 \%$ \\
\hline \multirow{2}{*}{2002} & 9462 & 26294 & 83347 & 148859 & 151876 & 112084 \\
\hline & $3.9 \%$ & $9.2 \%$ & $34.0 \%$ & $51.8 \%$ & $62.1 \%$ & $39.0 \%$ \\
\hline \multirow{2}{*}{2003} & 8526 & 22288 & 89437 & 170825 & 152344 & 168797 \\
\hline & $3.4 \%$ & $6.2 \%$ & $35.7 \%$ & $47.2 \%$ & $60.9 \%$ & $46.6 \%$ \\
\hline \multirow{2}{*}{2004} & 6452 & 23963 & 60375 & 175691 & 115723 & 151365 \\
\hline & $3.5 \%$ & $6.8 \%$ & $33.1 \%$ & $50.1 \%$ & $63.4 \%$ & $43.1 \%$ \\
\hline \multirow{2}{*}{2005} & 6519 & 24212 & 53265 & 155000 & 119227 & 155949 \\
\hline & $3.6 \%$ & $7.2 \%$ & $29.8 \%$ & $46.2 \%$ & $66.6 \%$ & $46.6 \%$ \\
\hline \multirow{2}{*}{2006} & 6666 & 24758 & 68123 & 198239 & 91318 & 119443 \\
\hline & $4.0 \%$ & $7.2 \%$ & $41.0 \%$ & $57.9 \%$ & $55.0 \%$ & $34.9 \%$ \\
\hline \multirow{2}{*}{2007} & 5828 & 21646 & 66360 & 193107 & 106632 & 139475 \\
\hline & $3.3 \%$ & $6.1 \%$ & $37.1 \%$ & $54.5 \%$ & $59.6 \%$ & $39.4 \%$ \\
\hline \multirow{2}{*}{2008} & 8529 & 31677 & 87652 & 255069 & 70056 & 91633 \\
\hline & $5.1 \%$ & $8.4 \%$ & $52.7 \%$ & $67.4 \%$ & $42.2 \%$ & $24.2 \%$ \\
\hline \multirow{2}{*}{2009} & 14233 & 52862 & 121338 & 353093 & 61924 & 80996 \\
\hline & $7.2 \%$ & $10.9 \%$ & $61.4 \%$ & $72.5 \%$ & $31.4 \%$ & $16.6 \%$ \\
\hline \multirow{2}{*}{2010} & 15808 & 58712 & 120302 & 350079 & 58861 & 76991 \\
\hline & $8.1 \%$ & $12.1 \%$ & $61.7 \%$ & $72.1 \%$ & $30.2 \%$ & $15.8 \%$ \\
\hline \multirow{2}{*}{2011} & 18183 & 67530 & 140051 & 407549 & 53900 & 70501 \\
\hline & $8.6 \%$ & $12.4 \%$ & $66.0 \%$ & $74.7 \%$ & $25.4 \%$ & $12.9 \%$ \\
\hline \multirow{2}{*}{2012} & 24955 & 92683 & 164226 & 477899 & 46741 & 61138 \\
\hline & $10.6 \%$ & $14.7 \%$ & $69.6 \%$ & $75.7 \%$ & $19.8 \%$ & $9.6 \%$ \\
\hline
\end{tabular}




\section{Material and Methods}

\section{Material}

The primary data used in this study were obtained from a face-to-face survey conducted at 100 dairy farms having a membership relationship with Agricultural Development Cooperatives, and continuing actively the dairy breeding with culture breed cows by providing the culture breed cows from them in Erzurum Province, Turkey. It has been selected the farms managing successfully the dairy breeding with the culture breed cattle for the last five years, and having enough farm assets and financial powers to maintain the dairy breeding activity.

\section{Methods}

Method used in determination of sample size: 4390 culture breed dairy cows were delivered by 33 Agricultural Development Cooperatives in order to develop the dairy farms in the scope of national agricultural policies in the last decade. Of these, while 11 sustained achievably the projects by maintaining their success trends in 2010; the others failed by leading to the animal loses partially or substantially. 11 cooperatives with 1410 culture breed dairy cows, therefore, were accepted as target main population. Of 11 cooperatives, on the other hand, 3 ones contracting with the farmers making the most successful and sustainable farming at 100 dairy farms with 416 culture breed cows in 2013 and their farmers were selected as sample population. These farms were located in Alaca and Toprakkale villages of Aziziye District, and in Yesiltepe, Kizilhasan and Mescitli ones of Ispir District.

Methods used in statistics analyses: After editing and coding, the data were first used in Principal Component Analysis (PCA) to determine the main factors by grouping the variables related to the pasture management and planning strategies. PCA is a data reduction technique that reduces the number of variables used in an analysis creating new variables that combine redundancy in the data (SPSS 15.0, 2006). The first step in PCA is to determine the number of relevant factors. This was conducted by PCA using Varimax Rotation Method (VRM). PCA was first used to determine the main attributes explaining a correlation among the structure and sources of dairy farms, the farmers' socioeconomic characteristics and management abilities, the attributes of dairy breed cattle and applied nutrition and feeding programs for them influencing on the milk yield, and the milk yields of the culture breed cattle. The purpose of PCA was to identify those attributes accounting for a relatively large proportion of the variance on the sample mass.

In the second step of statistics analysis, the main factors obtained from PCA and the attributes with regard to the nutrition and feeding program and the milk yields provided from the dairy farmers were used for Multiple Regression/Correlation (MRC) Analysis. The coefficient estimates were estimated by using Ordinary Least Squares (OLS). Individual and group significance of these coefficients were tested using $\mathrm{t}$ and $\mathrm{F}$ tests, respectively.

In order to evaluate whether to be any econometrical problem among the variables, on the other hand, it was tested the overall multicollinearity and auto-correlation problems by considering the variance-inflating factor (VIF) and Durbin-Watson d statistics, respectively (Gujarati, 2005; SPSS 15.0, 2006).

MRC model were given in following equation:

$$
\mathrm{AMIY}=f\left(\mathrm{a}, \mathrm{b}, \mathrm{c}, \mathrm{d}, \mathrm{e}, \mathrm{f}, \mathrm{g}, \mathrm{h}, \mathrm{i}, \mathrm{j}, \mathrm{k}, \mathrm{l}, \varepsilon_{\mathrm{i}}\right)
$$

Dependent Variable

AMIY : Annual milk yield per culture breed
Independent Variables (tons)

a $(\mathrm{HYCN}) \quad$ : Annual hay intake amounts per culture breed cow $(\mathrm{kg})$

$\mathrm{b}(\mathrm{BNCN}) \quad$ Annual cereal bran intake amounts per culture breed cow $(\mathrm{kg})$

$\mathrm{c}(\mathrm{CNCN})$ : Annual concentrate feed intake

amounts per culture breed cow $(\mathrm{kg})$

$\mathrm{d}(\mathrm{FDCN}) \quad$ : Annual fodder intake amounts per

e (PPLN) : Pasture planning for culture breed cow

$\mathrm{f}(\mathrm{AFTP}) \quad$ : Additional feeding and feed types at

pasture for culture breed cow

$\mathrm{g}$ (AFPP) : Additional feeding periods at pasture

for culture breed cow

$\mathrm{h}(\mathrm{CCSP}) \quad$ Culture breed cow supports of the

Government per dairy farm (\$)

i (FCSP) : Forage crop supports of the

Government per dairy farm (\$)

j (LCPR) : Lactation periods per culture breed

k (MKPR) : $\quad \begin{array}{ll}\text { cows } \\ \text { Milk sale price at farm yard (\$) }\end{array}$

1 (LQAS) : Liquid asset value per dairy farm $(\$)$

$\varepsilon_{\mathrm{i}} \quad$ Error term

\section{Results and Discussion}

\section{The Results of Descriptive Statistics}

The results of descriptive statistics with regard to the structural and socioeconomic properties of the dairy farms were indicated in Table 3. The results of the statistics showed that the average number of cattle and cow, the average lactation period, milk yield and the liquid assets and revenues of the farmers along with the average forage, hay, corn silage, cereal bran and concentrate feed intakes of dairy cattle were calculated as 10.60 and 4.20 heads, 219.70 days, $11.60 \mathrm{~kg} \mathrm{day}^{-1}$ head $^{-1}, 12.60$ tons and $\$ 3360.10$ per year, $\$ 92726.82$ along with 11.79 , 3.06, $0.20,2.17$ and $2.61 \mathrm{~kg} \mathrm{head}^{-1}$ per day, respectively.

\section{The Results of PCA}

Kaiser Normalization (KMO) which compares partial correlation coefficients with observed ones including in the pasture-based feeding and care management variables for the cows at the dairy farms in the research area was found as 0.73 , and this means that the data set for the PCA were at a good level since the test score was greater than 0.5. The PCA using Varimax Rotation Method grouped nine variables under the pasture-based feeding and care management conditions for the dairy cows into 
three main factors with Eigenvalues greater than 1, and the main factors explained the $58 \%$ of the total variance (Table 4).

\section{The Results of MRC Analysis}

The results of the statistical tests in Table 5 reported that VIF scores between 1.18 and 5.38, and 2.12 DurbinWatson $d$ statistic value between $d_{u}(1.92)$ and $4-d_{u}(1.44)$ did not caused any the econometrics problems for multicollinearity and auto-correlation in the MRC model (Gujarati, 2005; Kalayci, 2005). According to the results diagnosing the econometrics problems, the data sets could be used directly for the MRC model.

The determination statistics, OLS estimates of the parameter confidents and other statistic measurements such as F and t, collinearity and correlation matrix scores were given in Table 5. The results of the MRC analysis highlighted that the determination coefficient $\left(\mathrm{R}^{2}\right)$ and adjusted (adj.) $\mathrm{R}^{2}$ was calculated as 0.98 and 0.97 , and thus all the independent variables explained $97 \%$ of the dependent variable. The partial regression coefficients of all the independent variables considering $t$-statistics, except for BNCN and AFPP, found statistically important $(\mathrm{P}<0.01,0.05$ and 0.10$)$. On the other hand, the negative signs of the parameter coefficients for HYCN, PPLN, CCSP and LCPR with negative and the positive ones of the others were compatible with the economic theories.

The results of MRC analysis also indicated that while LQAS, CNCN, FDCN, MKPR, FCSP and AFTP influencing on the milk yields per the culture breed cows, and accepted as the important determinants of the dairy farms were of the strong $\left(\beta_{12}=0.394 \mathrm{P}<0.01\right)$, moderate $\left(\beta_{3}=0.242 \quad \mathrm{P}<0.01\right)$ and $\left(\beta_{4}=0.183 \quad \mathrm{P}<0.01\right)$, and light $\left(\beta_{11}=0.073 \quad \mathrm{P}<0.05\right), \quad\left(\beta_{9}=0.069 \quad \mathrm{P}<0.01\right), \quad\left(\beta_{6}=0.034\right.$ $\mathrm{P}<0.10)$ positive relations, respectively; HYCN, LCPR, PPLN and CCSP effecting on those had the strong $\left(\beta_{1}=0.326 \quad \mathrm{P}<0.01\right)$, moderate $\left(\beta_{10}=0.178 \quad \mathrm{P}<0.01\right)$ and light $\left(\beta_{5}=0.071 \quad \mathrm{P}<0.05\right), \quad\left(\beta_{8}=0.048 \quad \mathrm{P}<0.10\right) \quad$ negative impacts, respectively.

The results of each attribute accelerating to the success of the dairy farms in this study were analyzed in line with the results of the studies conducted by each group researchers focused on LQAS providing enough financial power to sustain the dairy farming activities
(Topcu, 2014; Topcu, 2008), CNCN and FDCN based on the nutrition and feeding program with a ratio of $70-75 \%$ on the milk production cost (Gunduz and Dagdeviren, 2011; Sen, 2010; Wilde, 2006; Dillon et al., 2003; Topcu, 2003; Clark, 2001; K1lic, 2000), MKPR and FCSP contributing to decrease of the production cost by supporting financially all the attributes (Aksoy et al., 2012; Ozdogru, 2010; Topcu, 2008 and 2008a; Dobson et al., 2007; Hansson, 2007; Beerver, 2006), and AFTP affecting the milk yield at pasture bases (Sen, 2010; Hansson, 2007; Orhan and Kaygisiz, 2007; Cavalieri et al., 2006; Dillon et al., 2003).

On the other hand, the results of the study indicated that there were an inverse relationship between each of HYCN, LCPR, PPLN, CCSP and the milk yield per the dairy cow; and they were supported by the results of the previous researches associated with HYCN (Topcu, 2008; Topcu, 2003; Kilic, 1993), LCPR (Walsh et al., 2011; Topcu, 2008; Dobson et al., 2007; Mulligan et al., 2006; Kaya, 2003), PPLN (Sen, 2010; Hansson, 2007; Orhan and Kaygısız, 2007; Cavalieri et al., 2006; Dillon et al., 2003), and CCSP (Aksoy et al., 2012; Ozdogru, 2010; Topcu, 2008a; Hansson, 2007).

\section{Conclusion}

In this study, the integrated management patterns based on not only the indoor barn and pasture-based production system managements but also the nutrition and feeding program along with the farmers' financial forces impacting on the successes of the dairy farms with culture breed cattle were evaluated. The measurement results of the study highlighted clearly that while there was a linear relationship between LQAS, CNCN, FDCN, MKPR, FCSP, AFTP attributes and the milk yield per the dairy cow at the dairy farms; there was an inverse relationship between HYCN, LCPR, PPLN, CCSP attributes and that. If the attributes affecting positively the milk yield at the dairy farms, therefore, are improved/increased; however, those influencing negatively are also decreased or shorted/removed, the successful of the dairy farms could be increased considerably under integrated management approaches.

Table 3 The results of some descriptive statistics with regard to the dairy farms with culture breed cattle

\begin{tabular}{|c|c|c|}
\hline Some structural variables & Means & Std. Dev. \\
\hline Total cattle number (head) & 10.60 & 4.60 \\
\hline Total culture breed dairy cow number (head) & 4.20 & 3.30 \\
\hline Lactation period (days) & 219.70 & 42.70 \\
\hline Milk yield $\left(\mathrm{kg}\right.$ head ${ }^{-1}$ day $\left.^{-1}\right)$ & 11.60 & 2.30 \\
\hline Total milk production (ton) & 12.60 & 14.30 \\
\hline Total milk income ${ }^{*}\left(\$\right.$ year $\left.^{-1}\right)$ & 3360.10 & 9732.20 \\
\hline Total liquid asset value $(\$)$ & 92726.82 & 26135.80 \\
\hline Forage consumption $\left(\mathrm{kg} \mathrm{head}^{-1}\right)$ & 11.79 & 4.55 \\
\hline Hay consumption $\left(\mathrm{kg} \mathrm{head}^{-1}\right)$ & 3.06 & 1.71 \\
\hline Corn silage consumption $\left(\mathrm{kg} \mathrm{head}^{-1}\right)$ & 0.20 & 1.41 \\
\hline Cereal bran consumption $\left(\mathrm{kg} \mathrm{head}^{-1}\right)$ & 2.17 & 0.46 \\
\hline Concentrate feed consumption $\left(\mathrm{kg} \mathrm{head}^{-1}\right)$ & 2.61 & 1.04 \\
\hline
\end{tabular}

$* 2.20 \mathrm{TL} / \$$ exchange rate converted from Turkish Lira (TL) to USA Dollar (\$) on March 15, 2014 was used in the calculations of the milk income and liquid asset value. 
Table 4 Attributes and correlated variable loadings related to pasture-based feeding for dairy cows

\begin{tabular}{|c|c|c|c|}
\hline \multirow{2}{*}{ Attributes interpretations and the variables } & \multicolumn{3}{|c|}{ Factor loadings $^{*}$} \\
\hline & F1 & F2 & F3 \\
\hline \multicolumn{4}{|l|}{ Pasture Planning (F1: PPLN) } \\
\hline Pastures return time & 0.849 & -0.035 & -0.012 \\
\hline Going time to pastures & 0.789 & 0.026 & 0.122 \\
\hline Pastures grass quality & 0.705 & -0.048 & 0.141 \\
\hline The region selection on the pastures & 0.570 & 0.321 & 0.040 \\
\hline \multicolumn{4}{|l|}{ Additional feeding and feed types at pasture (F2: AFTP) } \\
\hline Additional feeding & -0.215 & 0.755 & 0.020 \\
\hline Concentrate feed selection and types & 0.497 & 0.653 & -0.114 \\
\hline \multicolumn{4}{|l|}{ Additional feeding periods at pasture (F3: AFPP) } \\
\hline Additional feeding period & 0.225 & -0.086 & 0.709 \\
\hline Additional feeding requirements & 0.194 & -0.097 & 0.699 \\
\hline Additional feeding frequency & 0.062 & 0.408 & 0.563 \\
\hline Eigen-values & 2.892 & 1.265 & 1.038 \\
\hline Share of explained variance $(\%)$ & 32.129 & 14.058 & 11.536 \\
\hline Cumulative share of that $(\%)$ & 32.129 & 46.187 & 57.723 \\
\hline KMO (Kaiser-Meyer-Olkin) statistic & \multirow{2}{*}{\multicolumn{3}{|c|}{$\left[\begin{array}{r}0.728 \\
{\left[\text { Chi - square }\left(\lambda^{2}, d f: 36\right): 177.43\right](p=0.000)}\end{array}\right.$}} \\
\hline Bartlett's test of Sphericity & & & \\
\hline
\end{tabular}

*Bold numbers indicate the largest loading for each variable.

Table 5 The measurement results of MRC analysis and some statistic tests

\begin{tabular}{l|ccccccccc}
\hline \multirow{2}{*}{ Variables } & \multicolumn{3}{|c}{ Multiple linear regression $(\mathrm{MRC})^{2}$ model } & \multicolumn{3}{c}{ Correlations } & \multicolumn{2}{c}{ Collinearity statistics } \\
\cline { 2 - 9 } & Coefficients $^{\mathrm{a}}$ & Std. Error & $\mathrm{t}_{\mathrm{c}}$-value & $\mathrm{p}$-value & Zero-order & Partial & Part & Tolerance & VIF \\
\hline Constant & $(\alpha) 8.840$ & 1.757 & 5.031 & $0.000^{*}$ & - & - & - & - \\
HYCN & $\left(\beta_{1}\right)-0.326$ & 0.098 & -7.477 & $0.000^{*}$ & -0.840 & -0.625 & 0.142 & 0.189 & 5.278 \\
BNCN & $\left(\beta_{2}\right)-0.053$ & 0.262 & -1.005 & 0.318 & 0.827 & -0.107 & -0.079 & 0.232 & 4.598 \\
CNCN & $\left(\beta_{3}\right) 0.242$ & 0.129 & 4.186 & $0.000^{*}$ & 0.928 & 0.409 & 0.079 & 0.183 & 5.330 \\
FDCN & $\left(\beta_{4}\right) 0.183$ & 0.117 & 4.161 & $0.000^{*}$ & 0.686 & 0.407 & 0.079 & 0.186 & 5.380 \\
PPLN & $\left(\beta_{5}\right)-0.071$ & 0.072 & -2.294 & $0.024^{* *}$ & -0.652 & -0.239 & -0.043 & 0.372 & 2.689 \\
AFTP & $\left(\beta_{6}\right) 0.034$ & 0.048 & 1.655 & $0.100^{* * *}$ & 0.227 & 0.175 & 0.031 & 0.846 & 1.181 \\
AFPP & $\left(\beta_{7}\right) 0.023$ & 0.051 & 1.050 & 0.297 & 0.228 & 0.112 & 0.020 & 0.749 & 1.334 \\
CCSP & $\left(\beta_{8}\right)-0.048$ & 0.121 & -1.859 & $0.066^{* * *}$ & -0.272 & -0.195 & -0.035 & 0.535 & 1.870 \\
FCSP & $\left(\beta_{9}\right) 0.069$ & 0.122 & 2.639 & $0.009^{*}$ & -0.183 & 0.272 & 0.050 & 0.523 & 1.914 \\
LCPR & $\left(\beta_{10}\right)-0.178$ & 0.003 & -4.354 & $0.000^{*}$ & -0.199 & -0.423 & -0.083 & 0.216 & 4.633 \\
MKPR & $\left(\beta_{11}\right) 0.073$ & 2.060 & 2.558 & $0.012^{* *}$ & 0.433 & 0.264 & 0.049 & 0.444 & 2.253 \\
LQAS & $\left(\beta_{12}\right) 0.394$ & 0.000 & 5.184 & $0.000^{*}$ & 0.824 & 0.486 & 0.098 & 0.362 & 2.029 \\
\hline
\end{tabular}

n: 100; $\mathrm{R}^{2}: 0.98 ;$ Adj R ${ }^{2}: 0.97 ; \mathrm{F}_{\mathrm{c}(12,87)}: 224.49^{*} ; 1-\mathrm{d}_{\mathrm{u}}=1.44 ; \mathrm{d}_{\mathrm{u}}=1.92 ; \mathrm{DW} \mathrm{d}_{\mathrm{c}}=2.12 ;{ }^{\mathrm{a}}$ Coefficients consist of the standardized coefficients; ${ }^{*} \mathrm{P}<0.01$; ${ }^{* * *} \mathrm{P}<0.05 ;{ }^{* * *} \mathrm{P}<0.10$

Although this study has some scientific merit for the academic and milk producer and manufacturer communities, there are some limitations. The results of this study have a limited generalization since the data were obtained from only one city. If the survey is conducted nationally, more data could provide more objective results about integrated farm management patterns with respect to the milk production and yield decisions of the farmers, and this model could be expanded through the addition of more attributes in the future studies.

\section{References}

Aksoy A, Terin M, Keskin A. 2012. A Study on regional 1mpacts of breeding and support policy in dairy cattle sector in Turkey. Ataturk University Journal of Faculty of Agriculture 43: 59-64

Beerver DE. 2006. The impact of controlled nutrition during the dry period on dairy cow health, fertility and performance. Animal Reproduction Sciences 96: 212-226
Cavalieri J, Hepworth G, Fitzpatrick LA, Shephard RW, Macmillan KL. 2006. Manipulation and control of the estrous cycle in pasture-based dairy cows. Theriogenology 65: $45-64$

Cook NB, Nordlund KV. 2009. The influence of the environment on dairy cow behavior, claw health and herd lameness dynamics. Veterinary of Journal 179: 360-369

Clark JH, Klusmeyer TH, Cameron MR. 1992. Microbial protein synthesis and flows of nitrogen fractions to the duodenum of dairy cows. Journal of Dairy Science 75: 2304-2323

Dillon P, Buckley F, O’Connor P, Hegarty D, Rath M. 2003. A comparison of different dairy cow breeds on a seasonal grass-based system of milk production: Milk production, live weight, body condition score and DM intake. Livestock Production Science 83: 21-33

Dobson H, Smith RF, Royall MD, Knight CH , Sheldon IM. 2007. The high-producing dairy cow and its reproductive performance. Reproduction Domestic Animal 42(2): 17-23

FAOSTAT. 2014. Food and Agriculture Organization of the United Nations: Primary Livestock. (Access address: http://faostat3.fao.org/faostat-gateway, access date: 31.09.2014) 
Gujarati DN. 2005. Basic Econometrics. Reference Publish: 33, ISBN 975-7860-99-9, Istanbul, Turkey

Gunduz O, Dagdeviren M. (2011). Determining milk cost and the functional analysis of the factors affecting the milk production in Bafra District. YYU Journal of Agriculture Science 21(2): 104-111

Hansson H. 2007. Strategy factors as drivers and restraints on dairy farm performance: Evidence from Sweden. Agricultural Systems 94: 726-737

Honorato LA, Machado Filho LCP, Barbosa Silveira ID, Hötzel MJ. 2014. Strategies used by dairy family farmers in the south of Brazil to comply with organic regulations. Journal of Dairy Science 97(3): 1319-1327

Ingvartsen KL. 2006. Feeding and management related diseases in the transition cow Physiological adaptations around calving and strategies to reduce feeding-related diseases. Animal Feed Science and Technology 126: 175-213

Kalayci S. 2005. SPSS applications, multi-variables statistics techniques. Asil Publish, First Edition, ISBN 975-9091-143, Ankara, Turkey

Kaya A. 2003. The researches on the parameter estimate related to lactation length levels of culture breed cows and their milk yields. Animal Production 44(1): 76-94

Kilic A. 2000. Forage production and problems. Camber of Agriculture Enginiring 5th Technical Congress: 25-27 September, Ankara, Turkey, pp. 32-41

Kilic F. 1993. The analyses of the current condition analyses and the adaption of the dairy cows imported for Koceli Province. Master Thesis, Trakya University (Unpublished), Turkey

Mulligan FJ, O’Grady L, Rice DA, Doherty ML. 2006. A herd health approach to dairy cow nutrition and production diseases of the transition cow. Animal Reproduction Science 96: 331-353

Neveu C, Baurhoo B, Mustafa A. 2014. Effect of feeding extruded flaxseed with different grains on the performance of dairy cows and milk fatty acid profile. Journal of Dairy Science 97(3): 1543-1551

Orhan H, Kaygisiz A. 2007. A research on the estimation of variance components with regard to the milk yield of the culture breed cows. SDU Journal of Agriculture Faculty 2(1): 1-6
Ozdogru T. 2010. The economic effectiveness analyses for the local farmer of Amasya Dairy Cows Cooperative. PhD Thesis, Ankara Universitesi (Unpublished), Turkey

Pryce JE, Royal MD, Garnsworthyc PC, Maod IL. 2004. Fertility in the high-producing dairy cow. Livestock Production Science 86: 125-135

Slots T, Butler G, Leifert C, Kristensen LH, Nielsen JH. 2009. Potentials to differentiate milk composition by different feeding strategies. Journal of Dairy Science 92(5): 20572066

SPSS 15.0. 2006. SPSS Base 15 User's Guide. Chicago, IL.

Sen C. 2010. A research on vegetative structural characteristics of the pastures in Kilis, Gaziantep. Master Thesis, Cukurova University (Unpublished), Turkey

Thatcher WW, Bilby TR, Bartolome JA, Silvestre F, Staples CR, Santos JEP. 2006. Strategies for improving fertility in the modern dairy cow. Theriogenology $65: 30-44$

Topcu Y. 2003. The functional analysis of life weight increase at the cattle fattening farms: the case of Erzurum. Journal of MPM 3: 129-143

Topcu Y. 2008. The analysis of the success factors in dairy farms: The case study of Erzurum Province. OMU Journal of Faculty of Agriculture 23(1): 17-24

Topcu Y. 2008a. Effective factors' analysis on willingness to utilize from farmers' agricultural support policies. Akdeniz University Journal of Faculty of Agriculture 21(2): 127-138

Topcu Y, Macit M, Kaya H, Kaya A. 2014. Technical and economic efficiency analyses of the productive performance and egg quality parameters in laying hens fed by diets containing raw and treated common vetch seed at different levels. Journal of Animal and Plant Science 24(2): 397-405

TUIK. 2013. Turkish Statistical Institute: Livestock products. (Access address: http://www.turkstat.gov.tr, Access date: 18.10.2014)

Walsh SW, Williams EJ, Evans AOC. 2011. A review of the causes of poor fertility in high milk producing dairy cows. Animal Reproduction Science 123: 127-138

West WJ. 2014. Nutritional strategies for managing the heatstressed dairy cow. Journal of Animal Science 77: 21-35

Wilde D. 2006. Influence of macro and micro minerals in the per-parturient period on fertility in dairy cattle. Animal Reproduction Science 96: 240-249. 